\title{
EDITORIAL
}

\section{... And losartan was no better than placebo}

The United States Food and Drug Administration (FDA) has establ ished stringent criteria to determine efficacy and safety of antihypertensive drugs. ${ }^{1}$ Although efficacy still merely needs to be defined with regard to the surrogate end-point, ie, blood pressure (and not with regard to morbidity and mortality), all antihypertensive drugs must be able to lower blood pressure and to do so over the full dosing interval which is, in most instances, 24 hours. Thus, we can be reassured that several statistically highly significant studies have documented that losartan's antihypertensive efficacy was greater than placebo and that this also was true at the end of the dosing interval. How then, is it possible that in the study of Mallion et $\mathrm{al}^{2}$ the antihypertensive efficacy of losartan during the last $6 \mathrm{~h}$ of a 24-h cycle was not different from placebo and that it was significantly inferior to tel mi sartan?

Several points need to be discussed before we can draw any conclusions: (1) The effects of losartan were, indeed, numerically different from placebo, al though this difference did not reach statistical significance. Indeed, a reduction of $6 \mathrm{~mm} \mathrm{Hg}$ in diastolic pressure was observed with losartan in clinic measurements, but this was merely $2.5 \mathrm{~mm} \mathrm{Hg}$ better than placebo. With a greater number of patients, the difference might have become statistically significant al though still not necessarily clinically relevant. Also, the FDA requires that clinic blood pressure levels and not 24-h ambulatory blood pressure monitoring are used to establish efficacy. Conceivably, losartan which has a relatively short half-life, may provide a less comprehensive coverage of a 24-h period than other longer acting angiotensin receptor inhibitors, such as telmisartan. ${ }^{3}$ (2) Several other comparative studies also documented that irbesartan, ${ }^{4,5}$ candesartan ${ }^{6}$ and valsar$\tan ^{7}$ have greater anti hypertensive efficacy than losartan. (3) In contrast to most other angiotensin receptor inhibitors, Iosartan seems to have a very shallow dose response curve. In patients whose blood pressure insufficiently responds to the starting

Correspondence: Dr FH Messerli, Ochsner Clinic, 1514 Jefferson Highway, New Orleans, LA 70121, USA dose of $50 \mathrm{mg}$, the recommendation of the manufacturer is not to uptitrate but rather to add a low dose diuretic. ${ }^{8}$ When looking back on the history of hypertension, it is distinctly unusual to market an antihypertensive drug in just one strength. However, there are substantial data that up-titration from 50 to 100 or even $150 \mathrm{mg}$ with losartan does little if anything to increase antihypertensive efficacy. ${ }^{9}$

What then are the reasons for Iosartan's shallow dose response curve and its relative loss of efficacy at the end of the dosing interval?

Losartan exerts most of its antihypertensive effect through its metabolite EXP 3174 and needs to be converted by the liver to this active metabolite. Unfortunately, Iosartan and its active metabolite EXP 3174 compete for the same All-1 receptors. The efficacy of Iosartan al one on blood pressure is considerably less marked than that of EXP 3174. Thus, by occupying the receptor, the weak antagonist losartan may prevent the more powerful EXP 3174 from exerting its full antihypertensive effect. In contrast, with most other angiotensin receptor antagonists the active compound binds directly with the All-1 receptor and can exert its full antihypertensive power. It is not surprising, therefore, that some of these compounds are more powerful and have a more prolonged duration of action than losartan.

Clearly, the differences between, ie, telmisartan and losartan as documented in the thorough study of $\mathrm{Mallion}$ et $\mathrm{al}^{2}$ are relatively small, and the clinical significance of such a difference in the blood pressure lowering potency remains to be determined. Possibly a twice-a-day dosing of Iosartan could improve blood pressure control during the last $6 \mathrm{~h}$ of a 24-h period. However, good blood pressure control during these last $6 \mathrm{~h}$ is particularly important because of the excessive risk of cardiovascular events that have been documented during this time period, ie, the early morning hours. All other factors being equal, a compound that has more powerful and longer lasting antihypertensive efficacy when given once a day, such as tel mi sartan, should be preferred over one that seems to lose part of its antihypertensive efficacy at the end of the dosing interval, such as losartan. 
Franz H Messerli

Department of Internal Medicine Section on Hypertensive Diseases Ochsner Clinic and Alton Ochsner Medical Foundation New Orleans, LA, USA

\section{References}

1 Division of cardio-renal drug products. Proposed guidelines for the clinical evaluation of antihypertensive drugs. Draft 5/09/88. Report by the United States Food and Drug Administration.

2 Mallion JM, Siche JP, Lacourciere Y, and the Telmisartan Blood Pressure Monitoring Group. ABPM comparison of the antihypertensive profiles of the selective angiotensin II receptor antagonists tel misartan and Iosartan in patients with mild-to-moderate hypertension. J Hum Hypertens 1999; 13: 657-664.

3 Messerli FH, Grossman E, Weber MA, Brunner HR. Angiotensin II receptor inhibition. In: Messerli $\mathrm{FH}$ (ed). The ABCs of Antihypertensive Therapy. 2nd edition. Authors' Publishing House and Raven Press: New York, 1999; (in press).
4 Kassler-Taub K et al. Comparative efficacy of two angiotensin II receptor antagonists, irbesartan and Iosartan in mild-to-moderate hypertensi on. Irbesartan/Losartan Study Investigators. Am J Hypertens 1998; 11(4 Pt 1): 445- 453.

5 Oparil $\mathrm{S}$ et al, on behalf of the Irbesartan/Losartan Study Investigators. An elective-titration study of the comparative effectiveness of two angi otensin II-receptor blockers, irbesartan and Iosartan. Clin Ther 1998; 20: 398-409.

6 Andersson OK, Nel dam S. The antihypertensive effect and tolerability of candesartan cilexetil, a new generation angiotensin II antagonist, in comparison with losartan. Blood Pressure 1998; 7: 53-59.

7 Hedner $T$ et al. A comparison of the angiotensin II antagonists val sartan and losartan in the treatment of essential hypertension. Am J Hypertens 1999; 12: 414-417.

8 Bunt T. Problems with interpreting the data in KasslerTaub et al's article comparing irbesartan and Iosartan. Am J Hypertens 1999; 12(1 Pt 1): 79-81.

9 Gradman AH et al. A randomized, placebo-controlled, double-blind, parallel study of various doses of Iosartan potassium compared with enalapril maleate in patients with essential hypertension. Hypertension 1995; 25: 1345-1350. 